\title{
ASSESSMENT OF THE HEMODYNAMIC \\ CHARACTERISTICS OF ABSORB BVS IN A PORCINE \\ CORONARY ARTERY MODEL
}

Erhan Tenekecioglu, $\mathrm{MD}^{1}$; Ryo Torii, $\mathrm{PhD}^{2}$; Christos Bourantas, $\mathrm{MD}, \mathrm{PhD}^{3}$; Mohammad Abdelghani,MD ${ }^{4}$; Carlos Collet, $\mathrm{MD}^{4}$; Yaping Zeng, $\mathrm{MD}, \mathrm{PhD}^{1}$; Rafael Cavalcante, $\mathrm{MD}, \mathrm{PhD}^{1}$; Yohei Sotomi, $\mathrm{MD}^{4} ;$; Tom Crake, $\mathrm{MD}^{3}$; Teguh Santoso, MD, $\mathrm{PhD}^{5}$; Patrick W. Serruys, MD, $\mathrm{PhD}^{1,6 \dagger}$

${ }^{1}$ Department of Interventional Cardiology, Erasmus University Medical Center, Thoraxcenter, Rotterdam, The Netherlands.

${ }^{2}$ Department of Mechanical Engineering, University College London, United Kingdom.

${ }^{3}$ Department of Cardiology, University College of London Hospitals, London, United Kingdom.

${ }^{4}$ Department of Cardiology, Academic Medical Center, University of Amsterdam, Amsterdam, The Netherlands.

${ }^{5}$ Department of Internal Medicine, Faculty of Medicine, Dr. Cipto Mangunkusumo and Medistra Hospitals, University of Indonesia, Jakarta, Indonesia.

${ }^{6}$ Imperial College, London, United Kingdom.

RUNNING TITLE: ESS IN BIORESORBABLE SCAFFOLD

${ }^{\dagger}$ Corresponding author:Patrick W. Serruys, MD, PhD, FACC, FECC

Professor of Cardiology Imperial College, London, United Kingdom

Emeritus Professor of Medicine Erasmus University, Rotterdam, The Netherlands

Westblaak 98, 3012KM, Rotterdam, The Netherlands.

Email: patrick.w.j.c.serruys@gmail.com 


\begin{abstract}
:
Background and aim: Local hemodynamic changes are one of the main factors that determines the vessel wall biological response after stent/scaffold implantation. Computational fluid dynamic studies provide an opportunity to investigate the rheological effects of implanted stent/scaffold. The aim of this study was to assess the local flow hemodynamic microenvironment in scaffolded segments in porcine coronary models.
\end{abstract}

Methods: In 6 epicardial coronary arteries of healthy mini-pigs, 6 Absorb bioresorbable vascular scaffolds (Absorb BVS) were implanted. Optical coherence tomography (OCT) was performed after scaffold implantation and the images were fused with the angiographic data to reconstruct the three dimensional coronary artery anatomy. Blood flow simulations were performed and endothelial shear stress (ESS) distribution was estimated for each scaffolded segment. In a linear mixed-effect model, the contributing factors for low $(<1.0 \mathrm{~Pa})$ ESS levels were assessed. At 30-day post-implantation, histopathological assessment was performed at 2 scaffold.

Results: In scaffolded segments, the median ESS was 0.57 (IQR: 0.29-0.99) Pa. In linear mixed-effect analysis, cross-section area was associated with low shear stress levels. In scaffolded segments, the percentage of the recirculation zones per scaffolded luminal surface was $3.26 \pm 2.07 \%$. At 30 -day histopathological assessment of implanted vessel segments revealed minimal injury score, minimal neointimal inflammation and minimal adventitial inflammation scores with moderate endothelial coverage. Fibrin accumulation were seen at $95.69 \pm 2.47 \%$ of the struts.

Conclusion: The thick rectangular strut design of the Absorb BVS incited flow disruptions with low shear stress inducing fibrin accumulation. CFD assessment can be used to guide improvements in the scaffold design for a more "hemo-compatible" geometry.

Key words: Endothelial shear stress; bioresorbable scaffold; computational fluid dynamic 


\section{Introduction:}

Bioresorbable scaffold (BRS) has been introduced to overcome the drawbacks of metallic drug-eluting stents such as late stent thrombosis-due to delayed/incomplete healing-, neoatherosclerotic lesion development, and permanent metallic caging engenders abnormal vessel wall physiology(1). Stent/scaffold implantation induces crucial changes in local hemodynamic microenvironment in the treated vessel segment that greatly influences the reaction of the vessel wall (2). Stent design was shown one of the factors related with the in-stent restenosis in coronaries implanted with variety of stent types (3).

Endothelial shear stress (ESS) appears an important conducive factor for the vessel wall response after stent/scaffold implantation (3). With its high resolution, optical coherence tomography (OCT) based in silico fluid dynamic models provide unique opportunity to study the effects of intracoronary stent/scaffold on the hemorheological changes in microenvironment(4). Following stent/scaffold implantation, computational fluid dynamic (CFD) studies have revealed disruptions in laminar flow and local alterations in ESS that can predispose the treated segments to platelet activation, intimal hyperplasia and as a consequence, thrombosis and in-stent re-stenosis(4).

Absorb bioresorbable vascular scaffold (Absorb BVS, Abbott Vascular, Santa. Clara, California, USA) is the first commercially-available BRS and has a long list of investigations. Following the Absorb scaffold implantation in diseased coronaries, lower ESS was shown to induce neointimal thickening during follow up (4). In the present exploratory study, we aimed at revealing the effect of device geometry and strut design on ESS distribution in Absorb BVS implanted vessel segments without any atherosclerotic disease in porcine coronary models. 


\section{Methods:}

Six Yucatan mini-swine pigs with healthy coronaries underwent percutaneous coronary intervention (PCI) via femoral access through a standard procedure(5). Overall, six Absorb BVS were implanted in 6 coronary arteries. The treated coronary arteries were studied by OCT imaging following the scaffold implantation. The animal study protocol was approved by the Institutional Animal Care and Use Committee and the study was conducted in accordance with the American Heart Association guidelines for preclinical research and the Guide for the Care and Use of Laboratory Animals(6).

\section{Device description:}

Absorb BVS is made of poly L-lactic acid (PLLA), coated with a layer of a 1:1 mixture of an amorphous matrix of poly D,L-lactic acid (PDLLA) and elutes everolimus ( $8.2 \mu \mathrm{g} / \mathrm{mm})$. Absorb BVS, which is manufactured using extrusion and laser machining techniques, has $157 \mu \mathrm{m}$ strut thickness and a design of in-phase zig-zag hoops linked with bridges (Figure-1).

\section{Data acquisition:}

Coronary angiography was performed using Siemens HiCor cardiac angiography system (Siemens, Erlangen, Germany). The treated vessel segments were scrutinized using a frequencydomain OCT system (C8-XR OCT Intravascular Imaging System; St. Jude Medical, St. Paul, MN, USA) that was pulled-back at a speed of $18 \mathrm{~mm} / \mathrm{sec}$. A non-occlusive flushing technique was used for blood clearance by injection of contrast media. The acquired data were stored in DICOM format and transferred to a workstation for further analysis.

\section{Coronary artery reconstruction:}

Coronary artery reconstruction was implemented using a well-established and validated methodology (7). In x-ray angiographic and OCT images, the radiopaque markers and the anatomical landmarks (i.e. side branches), identified both on angiography and OCT, were used to define the scaffolded segment and proximal-distal native vessel segments. 
In the segment of interest, the OCT images portraying the scaffolded and the native vessel were identified and analyzed at a $0.1 \mathrm{~mm}$ interval in the scaffolded segment and a $0.2 \mathrm{~mm}$ interval in the native vessel segment. The flow area -defined in the native segment by the lumen border and in the scaffolded segment by the adluminal side of the scaffold struts and by the luminal surface in the interstrut areas(8)- was then delineated.

Two post-procedure end-diastolic angiographic images with at least $30^{\circ}$-angle difference illustrating the segment of interest with minimal foreshortening were selected with the table in the isocenter. In these images, the luminal borders were detected for the segment of interest and used to extract the luminal centerline which was then used to define the 3D luminal centerline of the segment of interest(7). The flow area borders detected on OCT images were then superimposed perpendicularly onto the luminal centerline and anatomical landmarks, that is side-branches seen in both OCT and angiographic images were used to define the absolute orientation of the OCT frames(7).

\section{Blood flow simulation:}

The reconstructed 3D geometries were processed with CFD techniques. After finite volume mesh generation, blood flow was simulated and the ESS was estimated by solving the 3D NavierStokes equations (ANSYS Fluent, Canonsburg, Pennsylvania) (9). In order to evaluate the impact of the scaffold design on the local hemodynamic micro-environment, the mesh density around the scaffold struts and within the boundary layer of the flow field at inter-strut area was increased to have an average element edge of $30 \mu \mathrm{m}$ (equal to 0.25 of the thickness of the scaffold strut). Blood was assumed to be a homogeneous, Newtonian fluid with a viscosity of 0.0035 Pa.s and a density of 1,050 $\mathrm{kg} / \mathrm{m} 3$. At the inflow of the 3D CFD model, a steady flow profile was simulated. As shown in previous publications, no significant differences exist between the ESS estimated in pulsatile and steady flow simulation(10,11). For each reconstruction, blood flow was estimated by measuring, in the 2 angiographic projections, the number of frames required for the contrast agent to pass from the inlet to the outlet of the reconstructed segment, the volume of the reconstructed segment and the cine frame 
rate $(3,12)$. The arterial wall was considered to be rigid, consistent with what is expected postimplantation. No-slip conditions were applied to the scaffold surface. At the outlet of the model, zero pressure conditions were applied. ESS at the luminal surface was calculated as the product of blood viscosity and the gradient of blood velocity at the wall(13). The ESS was measured in the native and the scaffolded segments around the circumference of the lumen at a $5^{\circ}$ interval (sector) and along the axial direction at a $0.2 \mathrm{~mm}$ interval with the use of an in-house algorithm(4) (Figure 2). The recirculation zones in the vicinity of the struts were quantified based on the direction of the ESS vector and the centerline vector. Areas where the ESS vector had opposite direction to the centerline vector were considered to be exposed to recirculation.

\section{Histopathological analysis:}

Two animals from the study population were humanely euthanized for histopathological assessment at 30-day post-implantation. Other animals left for histological analysis at 180-days, 360days and 720-days post-implantation. Each of sacrificed animal had 1 implanted Absorb BVS. One Absorb BVS (Absorb BVS-6, 3.0x $18 \mathrm{~mm}$ ) was implanted in the RCA of the first animal, and the other one (Absorb BVS-2, 3.0x18mm) was implanted in the LCx of the second animal. Sections from the proximal, mid and distal portions of each scaffolded segments were cut on a rotary microtome at six microns, mounted and stained with hematoxylin and eosin (H\&E) and Movat pentachrome stains. All sections $(n=6)$ were examined by light microscopy for the presence of inflammation, thrombus, and vessel wall injury. The cross-sectional areas (external elastic lamina [EEL], internal elastic lamina [IEL], and lumen) of each scaffolded section were measured. Neointimal thickness was measured as the distance from the inner surface of each scaffold strut to the luminal border. Area measurements were used to calculate vessel layer areas with the following formulas: Medial Area = EEL Area- IEL Area, Neointimal Area = IEL Area- Lumen Area, \% Stenosis $=[1-($ Lumen Area / IEL Area) $]$ x 100. To compare neointimal organization and healing, data were collected on each scaffold section including, strut apposition to the vessel wall, fibrin deposition, calcification, granuloma and giant cell 
reactions and hemorrhage around the scaffold struts and was expressed as a percentage of the total number of struts in each section. A vessel injury score was calculated according to the Schwartz method (14). An overall neointimal inflammation (score 0-4) and adventitial inflammation (score 0-3) and fibrin value (score 0-3) were scored for each section. Scaffolded vessels with two or more granulomatous reactions around the scaffold struts in any section were assigned a neointimal inflammation "grade 4". A description of these scores is demonstrated in Table 1. Endothelial coverage was estimated and expressed as the percentage of the lumen circumference covered by endothelium.

\section{Statistical analysis:}

Continuous variables were tested for normality of distribution with Kolmogorov-Smirnov test and are presented as mean $\pm \mathrm{SD}$ or median (interquartile range) as appropriate. Categorical variables are presented as frequencies and percentages. Continuous variables were compared by the KruskalWallis test or Mann Whitney U test. Categorical variables were compared by the Pearson Chi-square test.

There were several layers of grouping within the data of the study; six animals (level 4) received scaffold implants in up to three different arteries (level 3), where only one scaffold was implanted in each artery. Each scaffolded segment has several cross-sections (level 2) and each circumferential contour was divided into 72 sectors ( $5^{\circ}$-subunits) (level 1) in which ESS was measured. As the data in the study have multi-level structure and unbalanced design, mixed effects models were used to analyze the data. Since the ESS data have a skewed distribution, square root transformations of the ESS data were performed to get a normal distribution for ESS data. The multi-level model was built with fixed effects on cross-sectional area, vessel type and the 5-degree subunits and random effects on animal ID, vessel type and cross-section ID. All computations were done using the statistical analysis program SPSS V.22, R V. 3.2.3(15) and the R package lme4(16). 


\section{Results:}

In the study animals $(n=6)$, one left anterior descending artery (LAD), 3 left circumflex arteries (LCx) and 2 right coronary arteries (RCA) were treated. All scaffolds were well-apposed to the vessel wall and there were no malapposed struts. The list of scaffold diameters, lengths, deployment pressures, post-implantation dilatation balloon pressures, post-implantation scaffold diameters and the implantation locations in the treated coronaries are shown in Table-2. The median ESS values and dimensions of the proximal non-scaffolded segment, scaffolded segment and the distal non-scaffolded segment are shown in Table-3.

In scaffolded segments, the median ESS was 0.57 (interquartile range [IQR]: 0.29-0.99) Pa. The histogram of ESS for the Absorb BVS (Figure 3) showed that, 75\% of the scaffolded surface was exposed to a low $(<1 \mathrm{~Pa})$, athero-promoting ESS environment (Figure-4). The mean percentage of recirculation area per scaffolded vessel segment surface area was 3.26 $\pm 2.07 \%$ (Figure-5). After setting the model with random and fixed effects variables, multi-level linear regression analysis revealed that an increase in the cross sectional area was associated with a significant decrease in ESS $(\mathrm{p}<0.00001)$.

The results of the histopathological analysis are shown in section level in Table 4 and device level in Table 5. At 30-day histopathological assessment, the sections from the scaffolded segments demonstrated minimal neointimal inflammation and minimal adventitial inflammation scores (Figure6). From all prepared histological sections $(n=6)$, totally 72 struts were analysed. Around strut fibrin deposition was moderate to severe (mean score $=2.50 \pm 0.24$ ) and seen at $95.69 \pm 2.47 \%$ of the evaluated struts. Calcification was seen at the majority (mean $=53.28 \pm 15.14 \%$ ) of strut borders in all sections. The luminal surface showed incomplete endothelialization with frequent adherent luminal inflammatory cells. There was no luminal thrombus in the scaffolded vessels. 


\section{Discussion:}

In this exploratory study, we investigated the effect of scaffold design and strut profile of Absorb BVS on local hemodynamic microenvironment in healthy coronary arteries of porcine models. The main findings were as follows: 1) Thick rectangular non-streamlined struts of Absorb BVS caused recirculations and related low shear stress zones within the scaffolded luminal surface 2) The histopathological analysis showed minimal injury, minimal neointimal and adventitial inflammation at scaffolded segments 3) There was moderate to severe fibrin accumulation around the struts. 4) Reendothelialization of the analysed struts were not sufficient.

The relation between stent/scaffold design and disrupted flow hemodynamics inducing neointimal tissue response and in-stent restenosis has been demonstrated previously (17). It's obvious that it's strenuous to evaluate this relationship through in vivo studies. Several in silico studies have demonstrated the impact of stent design on local hemodynamics after stent implantation(2). In the present study, the zig-zag hoop designed rings and thicker rectangular struts induced flow separations, stagnation zones and related lower shear stress zones in the vicinity of the struts in Absorb BVS.

After constitution of a new luminal surface with implanted scaffold struts, shifted shear stress induces several patho-biological mechanisms within the vessel wall(18). The luminal surface coverage ratio, the curvature status of the implanted vessel segment, the design of the stent/scaffold, the strut geometry, the implantation process itself (implantation pressure, post-dilatation pressure, etc), embedment status of the stent struts are the factors for altered shear stress levels in scaffolded segment(18). Twenty-six percent luminal coverage ratio of Absorb BVS which is higher than its metallic equivalent, leads to higher endothelial denudation. This increased endothelial denudation with lower shear stress zones sets an susceptible environment for increased neointimal thickening through a continuous inflammation within the vessel wall (19 20). However, adequate inter-strut distance(1.0 mm for Absorb BVS) enables the flow streamlines to recover their laminarity after the disruption around the rectangular thicker struts $(2122)$. This recovery should mitigate low shear stress levels on 
the vessel wall. While the lower shear stress levels at besides of the struts and at inter-strut zones induce neointimal hyperplasia, the top of the struts induce less tissue hyperplasia due to increased shear stress levels at top of the struts(4).The histopathological analysis confirmed the variety in neointimal response at top of the struts and inter-strut zones due to the different levels of shear stress at top of struts and inter-strut areas. Both those mechanisms, adequate inter-strut distance and higher shear stress levels at top of the struts, with the anti-proliferative drug have counteracting effect for increased neointimal hyperplasia at follow up post implantation in Absorb BVS $(4,23)$.

Inadequate re-endothelialization of the scaffold struts at 30-day histological analysis might be the result of several factors. The flow disruption in the scaffolded segment impairs nitric oxide production which has influence on physiologic endothelial homeostasis (24). Non-laminar flow at strut zones probably affected the endothelial migration at these areas. Another factor might be the increased anti-proliferative drug uptake by the vessel tissue due to the stagnation zones in the lower shear zones beside the struts. These stagnation zones can induce clotting process which affects the anti-proliferative drug kinetics. Increased fibrin accumulation around the struts within the histological specimens supports this pathomechanism in our study. In silico models approved the drug recycle between the thrombus and the lumen that prohibits the drug to pass from clot around the strut to the vessel wall and cause accumulation of the drug around the struts which can prevent the endothelial regeneration at strut zones (25). In the absence of an laminar shear stress, endothelial differentiation of several types of stem cells is deteriorated which also may help to explain the defective re-endothelialization of the struts at 30-day in our study $(26,27)$.

\section{Limitations:}

There are some limitations in this research study. First, scaffold implantation was performed in healthy coronary vessels. Therefore, it was not possible to assess the impact of scaffold underexpansion or of the composition of the underlying plaque on strut embedment which can influence the flow hemodynamics in scaffolded segments. Second, there was no comparator which would enable to 
make a hypothesis for the hemo-rheologic properties of Absorb BVS. Third, in this exploratory study, at 30-day post-implantation, only two animals were sacrificed for histological analyses that was very limited for making a generalized comment for the histological analysis. Other animals will be euthanized at 180-day, 360-day and 720-day post-implantation for histological assessment.

\section{Conclusion:}

With its current design and strut profile, Absorb BVS induces fluctuations at ESS and related pathologic findings in scaffolded segments. The CFD examination should be handled delicately in order to improve the design characteristics of Absorb BVS in such a "hemo-compatible" way with reducing its strut thickness, converting the struts profile into a more streamlined form.

\section{Disclosures:}

E. Tenekecioglu has a research grant from TUBITAK (The Scientific Council of Turkey). P.W. Serruys is a member of the International Advisory Board of Abbott Vascular. Y. Onuma is a member of the International Advisory Board of Abbott Vascular. 


\section{References:}

1) Mukete BN, van der Heijden LC, Tandjung K, Baydoun H, Yadav K, Saleh QA, Doggen CJ, Rafeh NA, Le Jemtel TH, von Birgelen C. Safety and efficacy of everolimus-eluting bioresorbable vascular scaffolds versus durable polymer everolimus-eluting metallic stents assessed at 1-year follow-up: A systematic review and meta-analysis of studies. Int J Cardiol. 2016;221:1087-1094

2) Jimenez JM, Davies PF. Hemodynamically driven stent strut design. Annals of biomedical engineering 2009;37:1483-94.

3) Kastrati, A. J., Mehilli, J., Dirschinger, J., Pache, J., Ulm, K., Schuhlen, H., et al., , "Restenosis After Coronary Placement of Various Stent Types,” Am J Cardiol. 2001;87(1):34-9.

4) Bourantas CV, Papafaklis MI, Kotsia A, Farooq V1, Muramatsu T, Gomez-Lara J, Zhang YJ, Iqbal J, Kalatzis FG, Naka KK, Fotiadis DI, Dorange C, Wang J, Rapoza R, Garcia-Garcia HM, Onuma Y, Michalis LK, Serruys PW. Effect of the endothelial shear stress patterns on neointimal proliferation following drug-eluting bioresorbable vascular scaffold implantation: an optical coherence tomography study. JACC Cardiovascular interventions 2014; 7: 315-24.

5) Williams PD, Malik N, Kingston PA. Coronary angiography and percutaneous coronary intervention in the porcine model: a practical guide to the procedure. Animal. 2012;6(2):311-320.

6) National Research Council (U.S.). Committee for the Update of the Guide for the Care and Use of Laboratory Animals (2011). Guide for the Care and Use of Laboratory Animals. Washington, DC: National Academies Press.

7) Bourantas CV, Papafaklis MI, Lakkas L, Sakellarios A, Onuma Y, Zhang YJ, Muramatsu T, Diletti R, Bizopoulos P, Kalatzis F, Naka KK, Fotiadis DI, Wang J, Garcia Garcia HM, Kimura T, Michalis LK, Serruys PW. Fusion of optical coherence tomographic and angiographic data for more accurate evaluation of the endothelial shear stress patterns and neointimal distribution after bioresorbable scaffold implantation: comparison with intravascular ultrasound-derived reconstructions. Int J Cardiovasc Imaging. 2014;30(3):485-94. 
8) Nakatani S, Sotomi $Y$, Ishibashi $Y$, Grundeken MJ, Tateishi H, Tenekecioglu E, Zeng Y, Suwannasom P, Regar E, Radu MD, Räber L, Bezerra H, Costa MA, Fitzgerald P, Prati F, Costa RA, Dijkstra J, Kimura T, Kozuma K, Tanabe K, Akasaka T, Di Mario C, Serruys PW, Onuma Y. Comparative analysis method of permanent metallic stents (XIENCE) and bioresorbable polyL-lactic (PLLA) scaffolds (Absorb) on optical coherence tomography at baseline and follow-up. EuroIntervention. 2015;11(6).

9) Papafaklis MI, Bourantas CV, Theodorakis PE, Katsouras CS, Fotiadis DI, Michalis LK. Relationship of shear stress with in-stent restenosis: bare metal stenting and the effect of brachytherapy. International journal of cardiology 2009;134:25-32.

10) Feldman $C L$, Ilegbusi OJ, Hu $Z$, Nesto $R$, Waxman $S$, Stone $P H$ Determination of in vivo velocity and endothelial shear stress patterns with phasic flow in human coronary arteries: a methodology to predict progression of coronary atherosclerosis. Am Heart J. 2002;143(6):931-9.

11) Tenekecioglu E, Torii R, Bourantas $C$, Crake T, Zeng Y, Sotomi $Y$, Onuma Y, Yilmaz M, Santoso T, Serruys PW. Preclinical assessment of the endothelial shear stress in porcine-based models following implantation of two different bioresorbable scaffolds: effect of scaffold design on the local haemodynamic micro-environment. EuroIntervention. 2015;12(1). doi: 10.4244/EIJY16M05_01. [Epub ahead of print]

12) Sakamoto S, Takahashi S, Coskun AU, Papafaklis MI, Takahashi A, Saito S, Stone PH, Feldman CL. Relation of Distribution of Coronary Blood Flow Volume to Coronary Artery Dominance. Am J Cardiol 2013.

13) Stone PH, Saito S, Takahashi $S$, Makita $Y$, Nakamura S, Kawasaki T, Takahashi A, Katsuki T, Nakamura S, Namiki A, Hirohata A, Matsumura T, Yamazaki S, Yokoi H, Tanaka S, Otsuji S, Yoshimachi F, Honye J, Harwood D, Reitman M, Coskun AU, Papafaklis MI, Feldman CL; PREDICTION Investigators. Prediction of progression of coronary artery disease and clinical 
outcomes using vascular profiling of endothelial shear stress and arterial plaque characteristics: the PREDICTION Study. Circulation. 2012 Jul 10;126(2):172-81.

14) Schwartz RS, Huber KC, Murphy JG, Edwards WD, Camrud AR, Vlietstra RE, Holmes DR. Restenosis and the proportional neointimal response to coronary artery injury: results in a porcine model. J Am Coll Cardiol. 1992;19(2):267-274.

15) R Core Team. R: A Language and Environment for Statistical Computing. R Foundation for Statistical Computing, Vienna, Austria, 2015.

16) Bates $D$, Maechler M, Bolker B, and Walker S. lme4: Linear Mixed-Effects Models using 'Eigen' and S4, 2015. R package version 1.1-10.

17) Garasic JM, Edelman ER, Squire JC, Seifert P, Williams MS, Rogers C. Stent and artery geometry determine intimal thickening independent of arterial injury. Circulation 2000;101: 812-8.

18) Koskinas KC, Chatzizisis YS, Antoniadis AP, Giannoglou GD Role of endothelial shear stress in stent restenosis and thrombosis: pathophysiologic mechanisms and implications for clinical translation. J Am Coll Cardiol. 2012 Apr 10;59(15):1337-49.

19) Liehn EA, Schober A, Weber C Blockade of keratinocyte-derived chemokine inhibits endothelial recovery and enhances plaque formation after arterial injury in ApoE-deficient mice. Arterioscler Thromb Vasc Biol. 2004; 24(10):1891-6.

20) Gijsen FJ, Oortman RM, Wentzel $J J$ et al. Usefulness of shear stress pattern in predicting neointima distribution insirolimus-eluting stents in coronary arteries. Am $\mathrm{J}$ Cardiol. 2003;92(11):1325-8.

21) Berry JL, Santamarina A, Moore Jr JE, Roychowdhury S, Routh WD, Experimental and computational flow evaluation of coronary stents, Ann. Biomed. Eng. 28 (2000), 386-398.

22) Akagawa E, Ookawa $K$, Ohshima N. Endovascular stent configuration affects intraluminal flow dynamics and in vitro endothelialization. Biorheology. 2004;41(6):665-80. 
23) Serruys PW, Onuma $Y$, Garcia-Garcia HM, et al. Dynamics of vessel wall changes following the implantation of the absorb everolimus-eluting bioresorbable vascular scaffold: a multi-imaging modality study at 6, 12, 24 and 36 months. EuroIntervention. 2014 20;9(11):1271-1284.

24) Liu $X$, Wang $M$, Zhang $N$, Fan $Z$, Fan $Y$, Deng $X$. Effects of endothelium, stent design and deployment on the nitric oxide transport in stented artery: a potential role in stent restenosis and thrombosis. Med Biol Eng Comput. 2015;53(5):427-439.

25) Hwang $\mathrm{CW}$, Levin $\mathrm{AD}$, Jonas $\mathrm{M}$, Li PH, Edelman ER. Thrombosis modulates arterial drug distribution for drug-eluting stents. Circulation. 2005;111(13):1619-26

26) Potter $\mathrm{CM}$, Lao $\mathrm{KH}$, Zeng $\mathrm{L}$, $\mathrm{Xu}$ Q. Role of biomechanical forces in stem cell vascular lineage differentiation. Arterioscler Thromb Vasc Biol. 2014;34(10):2184-90.

27) Fang F, Wasserman SM, Torres-Vazquez J, Weinstein B, Cao F, Li Z, Wilson KD, Yue W, Wu JC, Xie X, Pei X. The role of Hath6, a newly identified shear-stress-responsive transcription factor, in endothelial cell differentiation and function. J Cell Sci. 2014;127(Pt 7):1428-1440. 


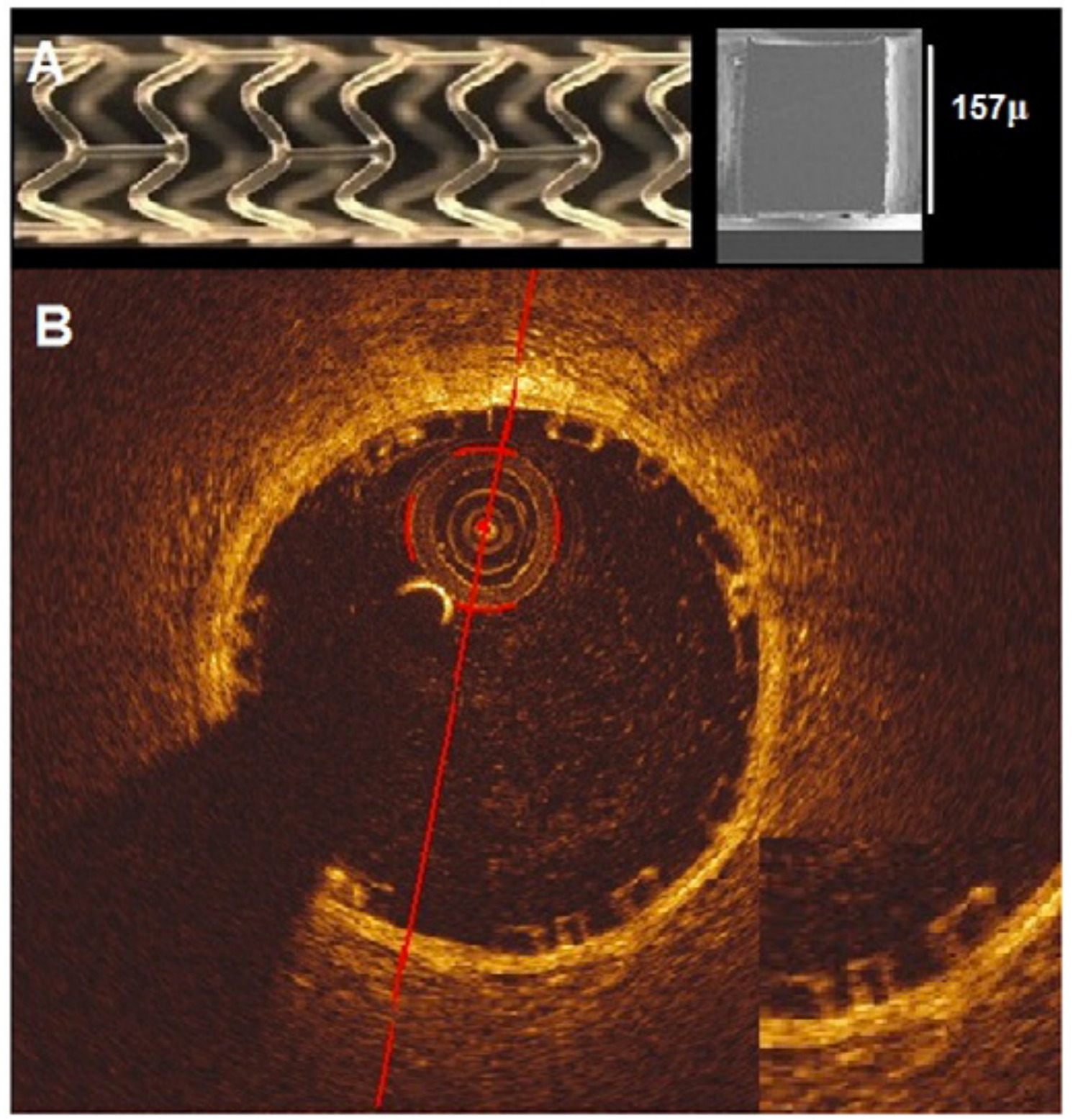

Figure 1: Absorb BVS 1.1 and the cross-section of Absorb BVS strut (A). OCT cross-section image of Absorb BVS. The strut of the Absorb BVS is rectangular and translucent(B). 


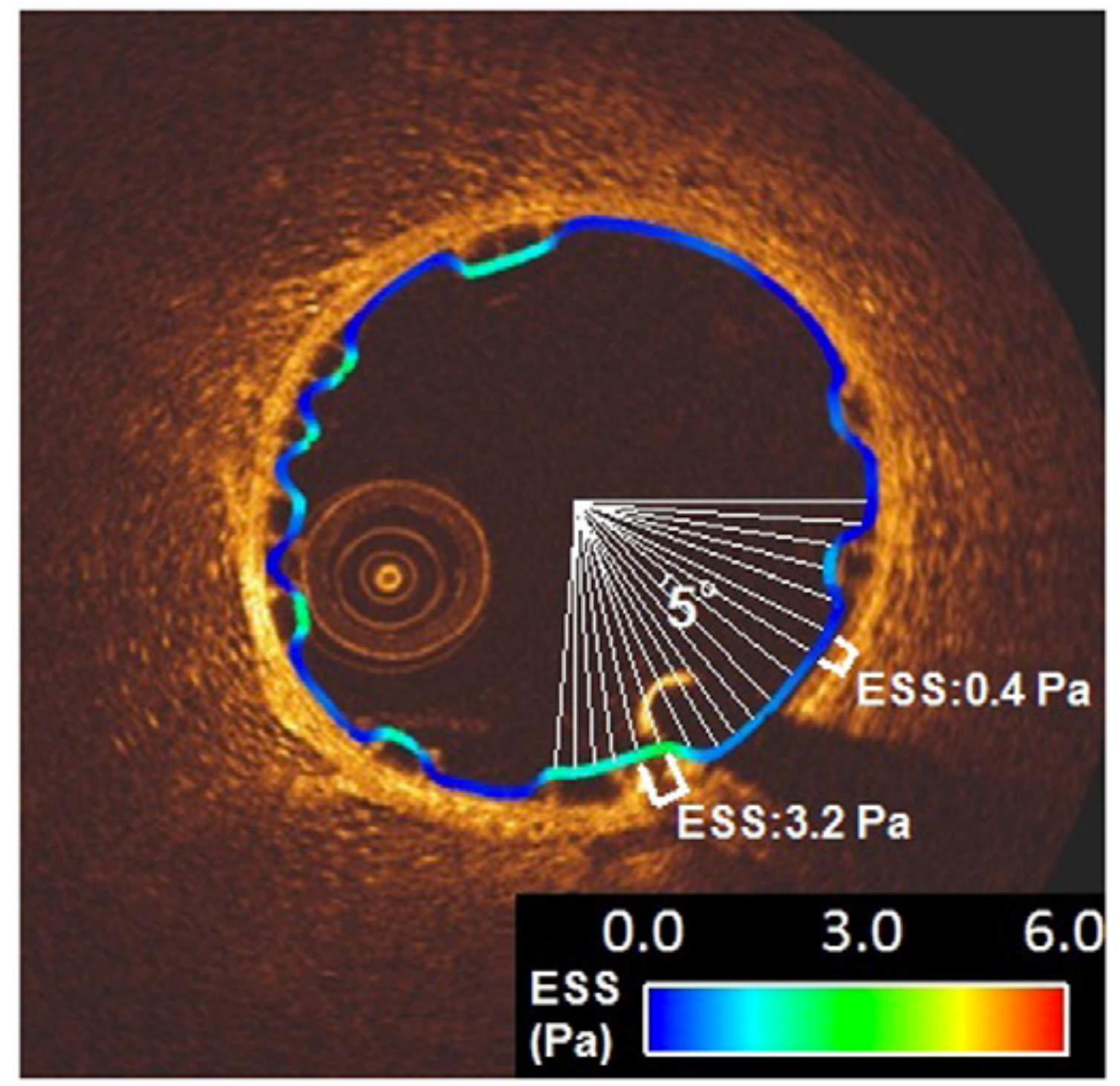

Figure 2: Circumferential ESS values (median, maximum and minimum) over the luminal perimeter at $5^{\circ}$-subunits (sectors) counted from 3 o'clock.

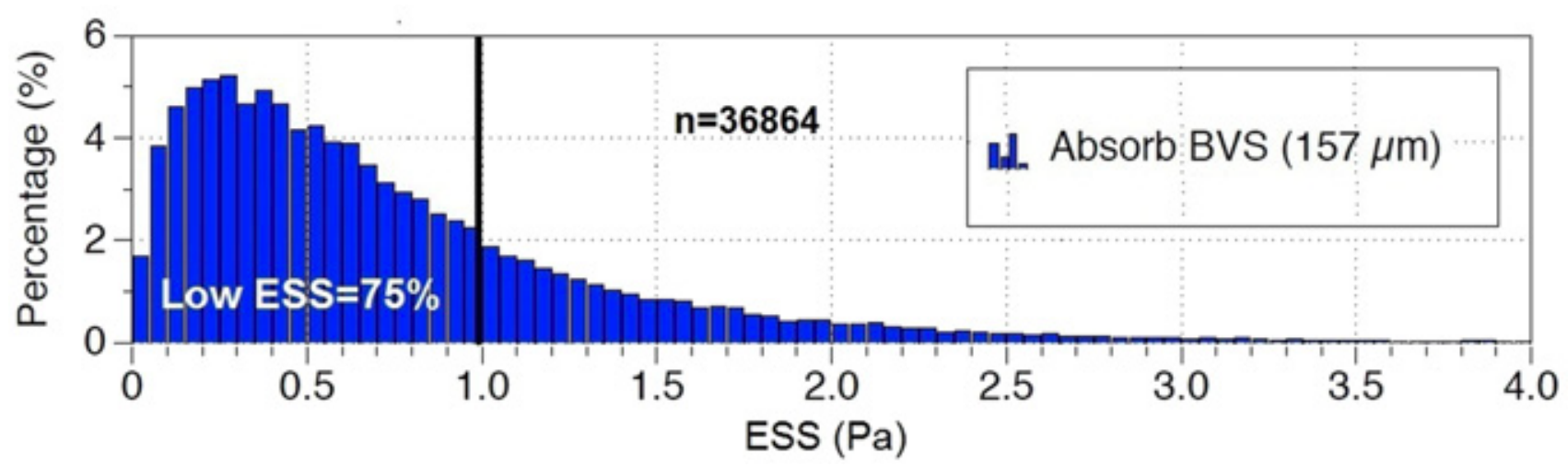

Figure 3: Histograms of ESS in scaffolded segments in Absorb BVS. "n" denotes the number of total ESS estimations at $5^{\circ}$-sectorial level. 


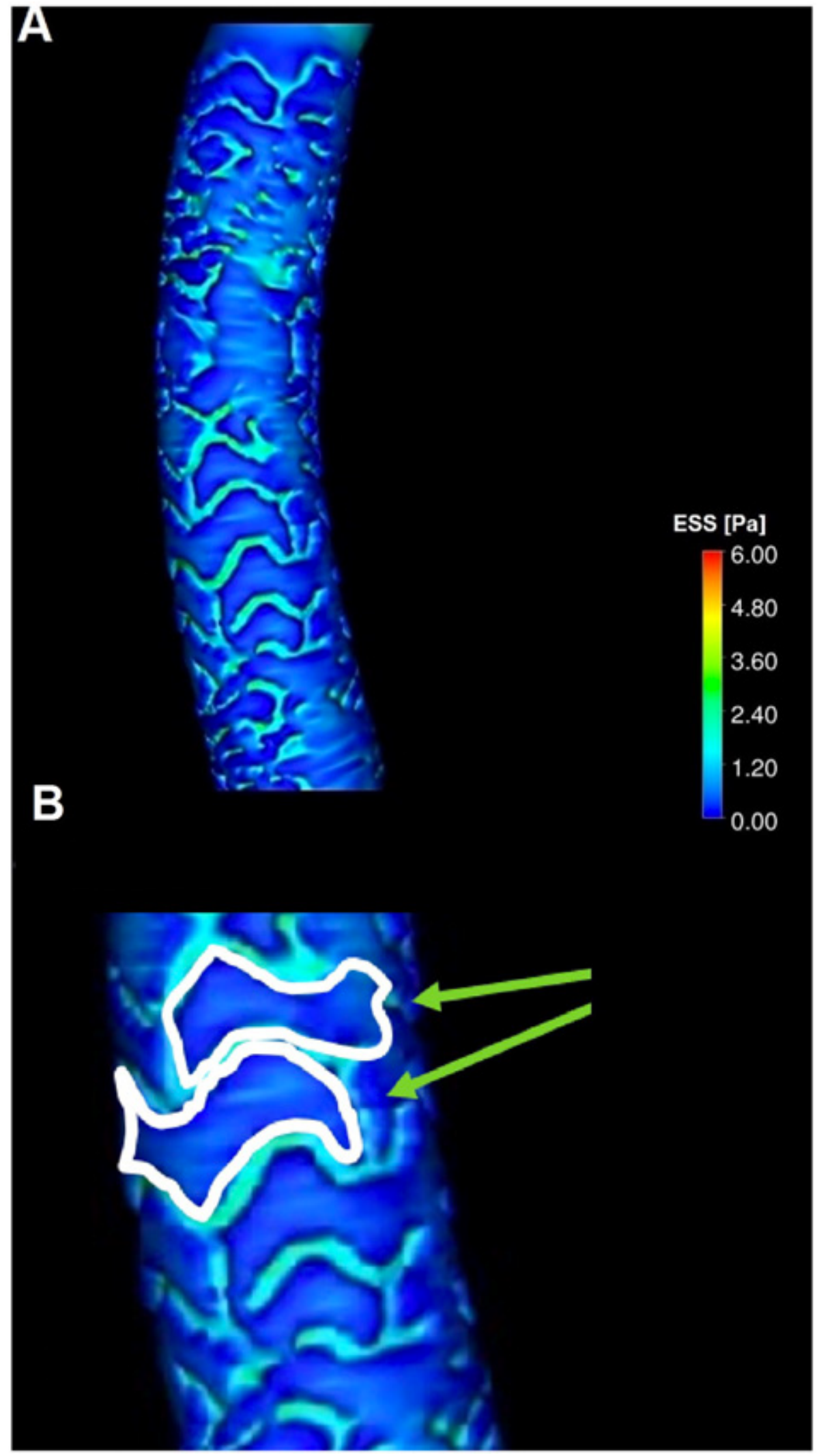

Figure 4: Three-dimensional reconstruction of scaffolded coronary anatomy from the fusion of coronary angiograms and OCT data with the local ESS being portrayed in a color-coded map (dark blue indicates low $\mathrm{ESS}<1.0 \mathrm{~Pa}$ and aquamarine an $\mathrm{ESS} \geq 1.0 \mathrm{~Pa}$ ) for Absorb BVS (A and B). 


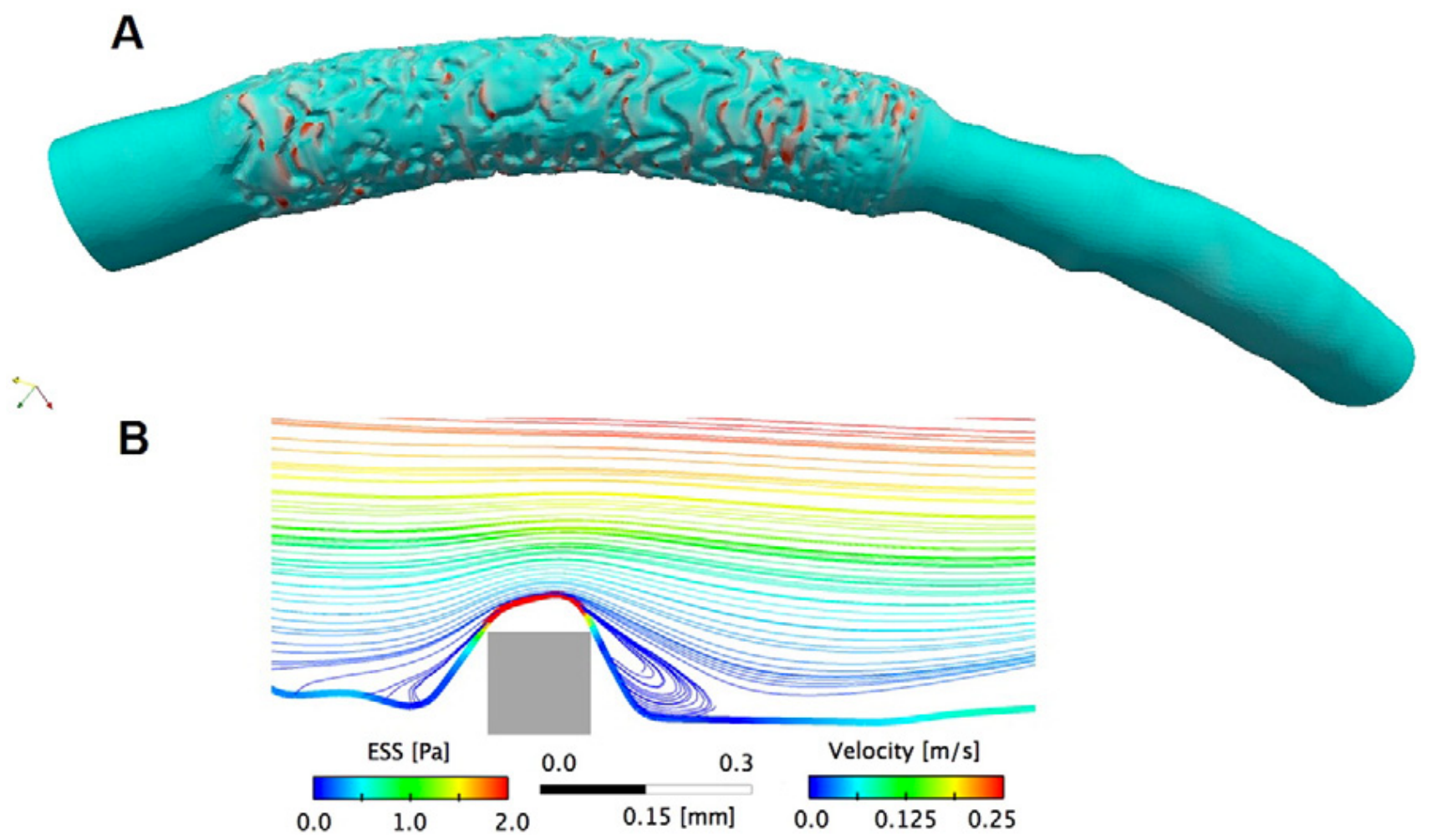

Figure 5: Recirculation zones(red) were quantified based on the ESS and the centerline direction (proximal $\rightarrow$ distal). The red areas in the luminal surface are where the vectors of the ESS are pointing opposite (more than 90-degrees away from) the proximal-to-distal direction along the centerline (A). Rectangular cross-section induce recirculations upstream and downstream of the struts (B)
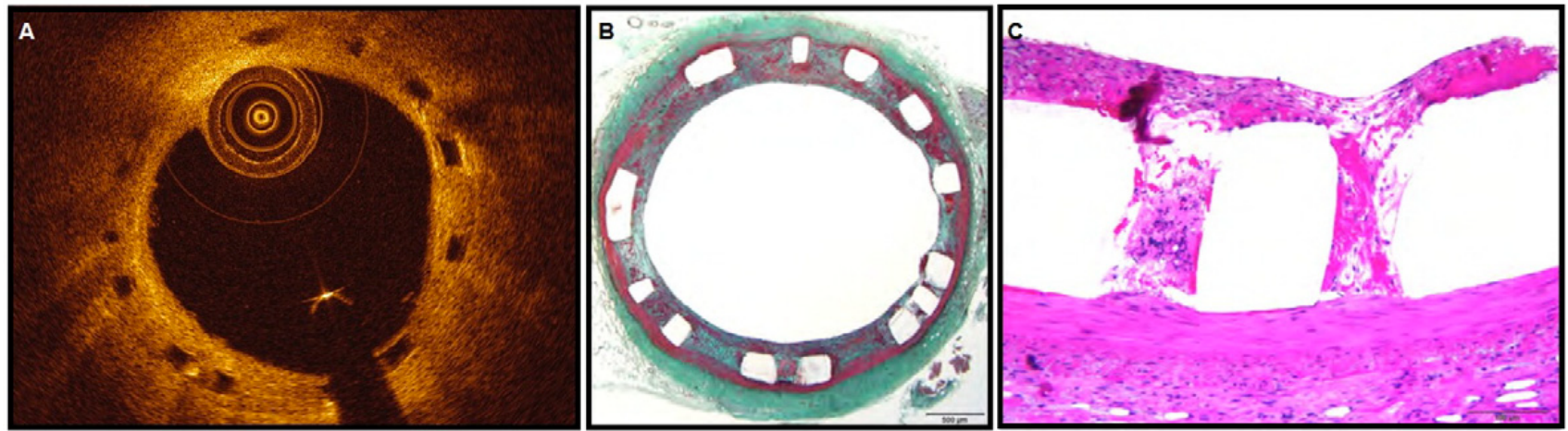

Figure 6: Low (2x) (A) and High (20x) (B) power representative image of Absorb BVS. Images shown are stained by Movat (2x) (A) and Hematoxylin and eosin (20x) (B). All struts were morphologically identical as open acellular regions with well-defined borders. Neointimal hyperplasia was thicker at inter-strut zones than top of the struts $(\mathrm{A}, \mathrm{B})$ 
Table-1: Description of Semi-Quantitative Histology Scores

\begin{tabular}{|c|c|c|}
\hline Attribute & Score & Description of Assigned Weight \\
\hline \multirow{4}{*}{$\begin{array}{l}\text { Injury Score } \\
\text { (Using the method } \\
\text { described by Schwartz } \\
\text { et } \mathrm{al}^{14} \text { ) }\end{array}$} & 0 & $\begin{array}{l}\text { Internal elastic lamina (IEL) intact, endothelium typically denuded, media may } \\
\text { be compressed but not lacerated }\end{array}$ \\
\hline & 1 & IEL lacerated, media typically compressed but not lacerated \\
\hline & 2 & $\begin{array}{l}\text { IEL lacerated, media visibly lacerated, external elastic lamina (EEL) intact but } \\
\text { may be compressed }\end{array}$ \\
\hline & 3 & $\begin{array}{l}\text { EEL lacerated, typically large lacerations of media extending through EEL, coil } \\
\text { wires sometimes residing in adventitia }\end{array}$ \\
\hline \multirow{5}{*}{$\begin{array}{l}\text { Neointimal } \\
\text { Inflammation Score }\end{array}$} & 0 & $<25 \%$ struts with fewer than 10 inflammatory cells \\
\hline & 1 & Up to $25 \%$ struts with greater than 10 inflammatory cells \\
\hline & 2 & $25-50 \%$ struts with greater than 10 inflammatory cells \\
\hline & 3 & $>50 \%$ struts with greater than 10 inflammatory cells \\
\hline & 4 & 2 or more struts with associated granulomatous inflammatory reactions \\
\hline \multirow[t]{4}{*}{ Fibrin Score } & 0 & No fibrin is appreciated (or only small strands) \\
\hline & 1 & $\begin{array}{l}\text { At least } 25 \% \text { of struts involving confluent fibrin that surrounds up to } 25 \% \text { of the } \\
\text { strut circumference }\end{array}$ \\
\hline & 2 & $\begin{array}{l}\text { At least } 50 \% \text { of struts involving confluent fibrin that surrounds }>25 \% \text { of strut } \\
\text { Fibrin Score circumference }\end{array}$ \\
\hline & 3 & $\begin{array}{l}\text { All struts with confluent fibrin surrounding }>50 \% \text { of strut circumference or } 25 \text { - } \\
50 \% \text { of struts with confluent fibrin involving }>25 \% \text { of strut circumference with } \\
\text { extension or bridging between struts }\end{array}$ \\
\hline \multirow[t]{4}{*}{$\begin{array}{l}\text { Adventitial } \\
\text { Inflammation Score }\end{array}$} & 0 & $\begin{array}{l}\text { No inflammation to minimal interspersed inflammatory cells anywhere in the } \\
\text { adventitia }\end{array}$ \\
\hline & 1 & $\begin{array}{l}\text { Mild peripheral inflammatory infiltration or focally moderated in }<25 \% \text { of } \\
\text { adventitial area }\end{array}$ \\
\hline & 2 & $\begin{array}{l}\text { Moderate peripheral inflammatory infiltration or focally marked in } 25-50 \% \text { of } \\
\text { adventitial area }\end{array}$ \\
\hline & 3 & $\begin{array}{l}\text { Heavy peripheral inflammatory infiltration or focally marked in }>50 \% \text { of } \\
\text { adventitial area }\end{array}$ \\
\hline
\end{tabular}


Table 2: Inventory of scaffolds with implantation parameters.

\begin{tabular}{|c|c|c|c|c|c|c|c|}
\hline Scaffold & Animal & Vessel & $\begin{array}{l}\text { Saffolde } \\
\text { d vessel } \\
\text { segment }\end{array}$ & $\begin{array}{l}\text { Scaffold } \\
\text { size } \\
(\mathrm{mm})\end{array}$ & $\begin{array}{l}\text { Deployment } \\
\text { balloon } \\
\text { pressure(atm) }\end{array}$ & $\begin{array}{c}\text { Post- } \\
\text { dilatation } \\
\text { balloon } \\
\text { inflation } \\
\text { pressure(atm) } \\
\end{array}$ & $\begin{array}{l}\text { The diameter of the } \\
\text { scaffold after } \\
\text { implantation (in } \\
\text { vitro) } \\
\text { (mm) }\end{array}$ \\
\hline ABSORB BVS-1 & Animal-A & $\mathrm{LCx}$ & Prox & $3.0 \times 18$ & 7 & 7 & 3.0 \\
\hline ABSORB BVS-2 & Animal-B & $\mathrm{LCx}$ & Mid & $3.0 \times 18$ & 7 & 8 & 3.0 \\
\hline ABSORB BVS-3 & Animal-C & $\mathrm{LCx}$ & Prox & $3.0 \times 18$ & 7 & 8 & 3.0 \\
\hline ABSORB BVS-4 & Animal-D & $\mathrm{RCA}$ & Mid & $3.0 \times 15$ & 7 & 14 & 3.3 \\
\hline ABSORB BVS-5 & Animal-E & LAD & Mid & $3.0 \times 18$ & 7 & 7 & 3.0 \\
\hline ABSORB BVS-6 & Animal-F & RCA & Mid & $3.0 \times 18$ & 7 & 7 & 3.0 \\
\hline
\end{tabular}

Table 3: The median ESS and lumen area in OCT in scaffolded and non-scaffolded segment in OCT for each scaffold. The data are tabulated according to the ranking of ESS

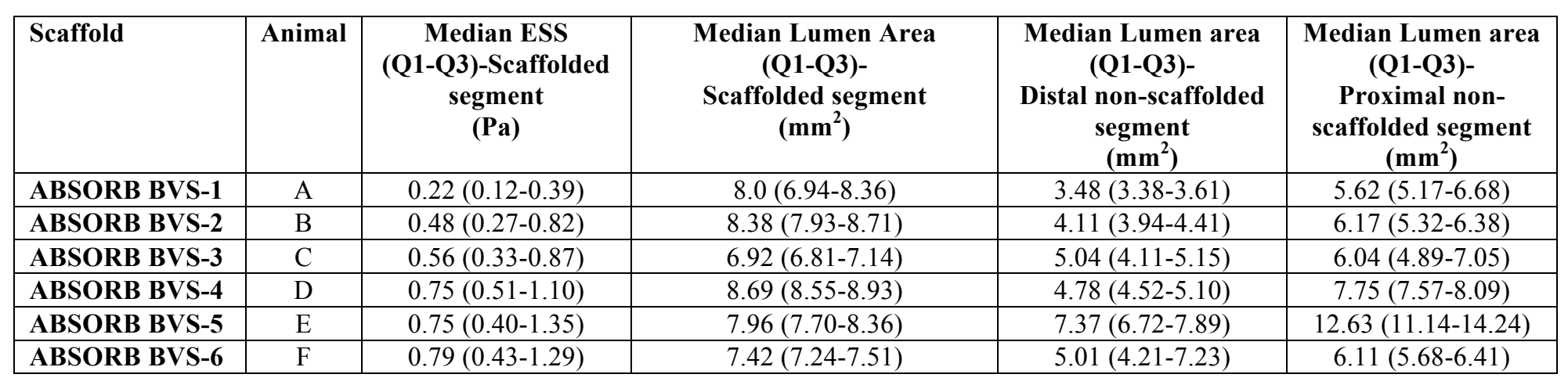


Table-4: Histo-pathological analysis of 2 scaffolded vessel segments. Histological findings from the proximal, mid and distal segments of the scaffolded segments.

\begin{tabular}{|c|c|c|c|c|c|c|c|c|c|c|c|c|c|c|c|c|c|c|c|}
\hline Scaffold & Ves. & Sec. & $\begin{array}{l}\text { EEL } \\
\text { Area }\end{array}$ & $\begin{array}{l}\text { IEL } \\
\text { Area }\end{array}$ & LA & NA & MA & $\begin{array}{l}\text { Ste. } \\
(\%)\end{array}$ & $\begin{array}{l}\text { NT } \\
\text { (Mn) }\end{array}$ & $\begin{array}{l}\text { Inj. } \\
\text { Sc }\end{array}$ & $\begin{array}{l}\text { Mal. } \\
\text { (\%) }\end{array}$ & $\begin{array}{l}\text { Fib } \\
(\%)\end{array}$ & $\begin{array}{l}\text { Fib } \\
\text { Sc }\end{array}$ & $\begin{array}{l}\text { Gran } \\
(\%)\end{array}$ & $\begin{array}{l}\text { N.inf } \\
\text { Sc }\end{array}$ & $\begin{array}{l}\text { Giant } \\
\text { cell } \\
(\%)\end{array}$ & $\begin{array}{l}\text { RBC } \\
(\%)\end{array}$ & $\begin{array}{l}\text { End. } \\
\text { cov. } \\
(\%)\end{array}$ & $\begin{array}{l}\text { Adv } \\
\text { Inf. } \\
\text { Sc }\end{array}$ \\
\hline $\begin{array}{l}\mathrm{D} 30-2 \\
\end{array}$ & LCx & Prox & 8.39 & 6.87 & 4.52 & 2.35 & 1.52 & 34.2 & 0.102 & 0.45 & 0.00 & 81.82 & 3 & 0.00 & 0 & 27.27 & 54.55 & 10 & 0 \\
\hline D30-2 & LCx & Mid & 8.32 & 7.01 & 4.58 & 2.43 & 1.31 & 34.7 & 0.126 & 0.92 & 0.00 & 100.0 & 3 & 0.00 & 0 & 8.33 & 75.00 & 20 & 0 \\
\hline D30-2 & LCx & Dist & 7.83 & 6.99 & 4.53 & 2.46 & 0.84 & 35.2 & 0.105 & 0.62 & 0.00 & 100.0 & 2 & 0.00 & 1 & 23.08 & 61.54 & 40 & 0 \\
\hline D30-6 & RCA & Prox & 7.96 & 6.97 & 4.29 & 2.68 & 0.99 & 38.5 & 0.130 & 0.00 & 0.00 & 100.0 & 2 & 0.00 & 0 & 41.67 & 41.70 & 99 & 0 \\
\hline D30-6 & RCA & Mid & 8.06 & 6.89 & 4.31 & 2.58 & 1.17 & 37.5 & 0.138 & 0.08 & 0.00 & 92.31 & 2 & 0.00 & 0 & 30.77 & 30.80 & 80 & 0 \\
\hline D30-6 & RCA & Dist & 8.87 & 7.53 & 4.28 & 3.25 & 1.34 & 43.2 & 0.217 & 0.45 & 0.00 & 90.00 & 3 & 0.00 & 0 & 63.64 & 45.45 & 90 & 0 \\
\hline
\end{tabular}

Ves : Vessel, Sec : Section, EEL: External elastic lamina, IEL: internal elastic lamina, NA: Neointimal area, MA : Medial area, Ste: Stenosis, NT(Mn): Neointimal thickness(Mean), Inj Sc: Injury score, Mal: Malapposition, Fib: Fibrin, Gran : Granulocyte, N.inf Sc: Neointimal inflammation score, RBC : Red blood cell, End. Cov. : Endothelial Coverage, Adv. Inf. Sc : Adventitial Inflammation score 
Table-5a: Morphometric analysis results from all sections (proximal, mid, distal) (mean \pm SD) at light microscopy.

\begin{tabular}{|c|c|c|c|c|c|c|}
\hline $\begin{array}{l}\text { EEL Area } \\
\left(\mathrm{mm}^{2}\right)\end{array}$ & $\begin{array}{c}\text { IEL Area } \\
\left(\mathrm{mm}^{2}\right)\end{array}$ & $\begin{array}{c}\text { Lumen Area } \\
\left(\mathrm{mm}^{2}\right)\end{array}$ & $\begin{array}{l}\text { Medial Area } \\
\left(\mathrm{mm}^{2}\right)\end{array}$ & $\begin{array}{l}\text { Neointimal } \\
\text { Area }\left(\mathrm{mm}^{2}\right)\end{array}$ & $\begin{array}{l}\text { Stenosis } \\
(\%)\end{array}$ & $\begin{array}{c}\text { Neointimal } \\
\text { Thickness (mm) }\end{array}$ \\
\hline $8.24 \pm 0.082$ & $7.04 \pm 0.12$ & $4.42 \pm 0.18$ & $1.20 \pm 0.040$ & $2.62 \pm 0.30$ & $37.19 \pm 3.53$ & $0.14 \pm 0.036$ \\
\hline
\end{tabular}

Table-5b: Histologic analysis results from all sections(mean \pm SD) at light microscopy.

\begin{tabular}{|c|c|c|c|c|c|c|}
\hline $\begin{array}{c}\text { Strut } \\
\text { Malapposition } \\
(\%)\end{array}$ & $\begin{array}{c}\text { Struts with } \\
\text { Fibrin } \\
(\%)\end{array}$ & $\begin{array}{c}\text { Struts with } \\
\text { Granuloma } \\
(\%)\end{array}$ & $\begin{array}{c}\text { Struts with } \\
\text { Giant Cells } \\
(\%)\end{array}$ & $\begin{array}{c}\text { Struts with } \\
\text { RBCs } \\
(\%)\end{array}$ & $\begin{array}{c}\text { Struts with } \\
\text { Calcification } \\
(\%)\end{array}$ & $\begin{array}{c}\text { Endothelialization } \\
(\%)\end{array}$ \\
\hline $8.24 \pm 0.082$ & $7.04 \pm 0.12$ & $4.42 \pm 0.18$ & $1.20 \pm 0.040$ & $2.62 \pm 0.30$ & $37.19 \pm 3.53$ & $0.14 \pm 0.036$ \\
\hline
\end{tabular}

Table-5c: Histologic analysis of non-parametric scores from all sections (mean $\pm \mathrm{SD}$ ) at light microscopy.

\begin{tabular}{|c|c|c|c|}
\hline $\begin{array}{c}\text { Mean Injury } \\
\text { Score }\end{array}$ & $\begin{array}{c}\text { Mean Fibrin } \\
\text { Score }\end{array}$ & $\begin{array}{c}\text { Neointimal Inflammation } \\
\text { Score }\end{array}$ & $\begin{array}{c}\text { Adventitial Inflammation } \\
\text { Score }\end{array}$ \\
\hline $8.24 \pm 0.082$ & $7.04 \pm 0.12$ & $4.42 \pm 0.18$ & $1.20 \pm 0.040$ \\
\hline
\end{tabular}

